Original Article

\title{
Epidemiological profile of viral hepatitis infection in the population treated at a reference hospital in Alagoas
}

\author{
Perfil epidemiológico da infecção por hepatite viral na população atendida em hospital \\ de referência em Alagoas
}

\author{
K. M. da Silva ${ }^{\mathrm{B}}$ (D) J. R. da S. Ferreira ${ }^{\mathrm{C}}$ (D) A. de P. M. de Carvalho Neto ${ }^{\mathrm{b}}$ (D), D. C. de S. Gomes ${ }^{\mathrm{b}}$ (D), \\ M. G. dos S. Cavalcantic (D) G. C. Ferreira-Júnior ${ }^{d}$ (D) and T. J. Matos-Rochaa,b* (D) \\ a Universidade Estadual de Ciências da Saúde de Alagoas - UNCISAL, Maceió, AL, Brasil \\ ${ }^{\mathrm{b}}$ Centro Universitário Cesmac, Maceió, AL, Brasil \\ ' Universidade Federal da Paraíba - UFPB, João Pessoa, PB, Brasil \\ 'Instituto Federal de Educação, Ciência e Tecnologia do Acre - IFAC, Xapuri, AC, Brasil
}

\begin{abstract}
Viral hepatitis are widely spread infectious diseases caused by a variety of etiological agents that displays liver tropism as a common characteristic. A descriptive, cross-sectional, observational and retrospective study was conducted through the analysis of viral hepatitis medical records treated and diagnosed from 2010 to 2015. The relationship between the variables were made through the chi-square test. 632 viral hepatitis medical records were analyzed. The highest number of cases happened in 2011. Hepatitis A virus (HAV) infection was predominant. The most affected age group was $<20$ years and the highest number of cases observed in this age group was related to HAV ( $p<0.001$ ). The acute clinical form was predominant, with $70.2 \%$ of the cases. $92.3 \%$ of which corresponded to HAV infection $(\mathrm{p}<0.001)$. Most of the cases occurred in the brown race and male gender. Moreover, regarding the probable source/mechanism of infection, the contact with suspicious water/food for hepatitis A cases was highlighted. The sexual form predominated in HBV infection and previous history of blood transfusion in cases of hepatitis C. Most cases were spotted in the mesoregion of Eastern Alagoas, especially in the capital Maceió. It must be observed the importance of knowing the profile of this disease in order to understand its dissemination and thus have subsidies for the creation of actions and strategies to combat the infection.
\end{abstract}

Keywords: viral hepatitis, epidemiological profile, Hepatitis A, Hepatitis B, Hepatitis C.

\begin{abstract}
Resumo
A hepatite viral é uma doença infecciosa amplamente difundida causada por uma variedade de agentes etiológicos que exibem o tropismo hepático como uma característica comum. Um estudo descritivo, transversal, observacional e retrospectivo foi realizado por meio da análise de prontuários de hepatites virais tratados e diagnosticados de 2010 a 2015. A relação entre as variáveis foi feita através do teste qui-quadrado. Foram analisados 632 prontuários de hepatite sustero. O maior número de casos aconteceu em 2011. A infecção pelo vírus da hepatite A (HAV) foi predominante. A faixa etária mais atingida foi $<20$ anos e o maior número de casos observados nessa faixa etária foi relacionado ao HAV ( $p<0,001$ ). A forma clínica aguda foi predominante, com 70,2\% dos casos. 92,3\% dos quais corresponderam à infecção por HAV $(\mathrm{p}<0,001)$. A maioria dos casos ocorreu na raça parda e no sexo masculino. Além disso, quanto à provável fonte/mecanismo de infecção, foi destacado o contato com água/alimento suspeitos para os casos de hepatite A. A forma sexual predominou na infecção pelo HbV e histórico anterior de transfusão de sangue em casos de hepatite C. A maioria dos casos foi avistada na mesorregião do Leste de Alagoas, especialmente na capital Maceió. Deve-se observar a importância de conhecer o perfil dessa doença para entender sua disseminação e, assim, contar com subsídios para a criação de ações e estratégias de combate à infecção.
\end{abstract}

Palavras-chave: hepatite viral, perfil epidemiológico, Hepatite A, Hepatite B, Hepatite C.

\section{Introduction}

Viral hepatitis are widely spread infectious diseases caused by a variety of etiological agents that displays liver tropism as a common characteristic (Nunes et al., 2010). They present distinct clinical, laboratory and epidemiological aspects, but show important particularities (Cruz et al., 2009). The last decades have been marked by several advances related to the prevention and control of this disease, such as the development of laboratory tests,

*e-mail: thiago.matos@uncisal.edu.br

Received: May 21, 2020 - Accepted: October 13, 2020 
vaccines and identification of causative agents (Brasil, 2015; Fonseca, 2010).

As viral hepatitis is a public health issue in Brazil, it has become a mandatory notification disease since 1998. Thus, all confirmed cases and outbreaks should be notified to the National Disease Notification System (SINAN) by completing the Viral Hepatitis Investigation Form. However, the data from the surveillance system still faces obstacles such as underdiagnosis and underreporting (Brasil, 2017). Between 1999 and 2015, 514,678 cases of viral hepatitis were reported to SINAN, in which 161.605 (31.4\%) were cases of hepatitis A, 196,701 (38.2\%) of hepatitis B, 152,712 (29.7\%) hepatitis C and 3.660 (0.7\%) hepatitis D (Brasil, 2017).

Hepatitis A is caused by an RNA virus belonging to the Picornavirus family. Its prevalence varies according to hygiene and sanitary conditions available to the population, hence being more frequent in developing countries where poor hygiene and basic sanitation and lack of drinkable water are most notable. The most common form of transmission is fecal-oral transmission and predominantly affects children and adolescents (Pereira and Gonçalves, 2003). In addition to vaccination, improving sanitary and hygiene conditions are the most effective measures to prevent hepatitis A infection (Prado and Miagostovich, 2014).

Hepatitis B virus (HBV) is a DNA virus belonging to the family Hepdanaviridae. It is found all throughout the world and exhibits a broad clinical spectrum (Azevedo et al., 2015). Its transmission occurs mainly through the parenteral and sexual pathways. In developed countries it is known that the infection is more prevalent among homosexual males, injecting drug users and those who have multiple sexual partners (Lok and McMahon, 2011). Hepatitis C virus (HCV) infection is one of the main causes of chronic liver disease and may present itself symptomatically or asymptomatically, with the potential of becoming chronic in both cases and is rarely presented in the acute form (Kao and Chen, 2000). The main routes of infection include blood transfusion, percutaneously (sharing syringes, needles, personal use objects, tattooing and piercings). Congenital and sexual pathways are also recognized but with a lower rate of transmission (Oliver et al., 2013). Since the hepatitis D virus (VHD) relies on HBV to complete its biological cycle and become infectious, it is more prevalent in hepatitis $B$ endemic areas, where VHD infection represents a serious public health problem. In addition, it has transmission mechanisms identical to that of the HBV (Brasil, 2018).

Hepatitis $\mathrm{E}$ is distributed worldwide with an estimated 20 million infections and 56,000 deaths per year. The form of transmission is fecal-oral, through the ingestion of contaminated water and food (Nunes et al., 2016). The objective of this study is to expand the knowledge about the epidemiological profile of viral hepatitis in the population treated in a reference hospital in Alagoas, analyzing the following variables: gender, age group, etiological classification, year of diagnosis, origin, clinical form, race and probable mechanism of infection related to the disease studied.

\section{Materials and Methods}

A descriptive, cross-sectional, observational and retrospective study was conducted. The data used was gathered from the analysis of medical records, provided by the Medical and Statistical Archive Service, with cases of viral hepatitis treated at the Hospital Escola Dr. Hélvio Auto which is a reference hospital in the care and treatment of infectious diseases in the State of Alagoas. All viral hepatitis cases were included in the study, which met the criteria of suspected cases and laboratory confirmation, served at the study site from January 2010 to December 2015 regardless of gender and age group. Cases treated outside this timeframe, those that did not present laboratory confirmation by serology or were not checked or those that were not possible to access the results of laboratory tests were excluded from the study.

Data collection was performed using a structured form containing the following variables: etiology, year of diagnosis, gender, race, clinical form, age group, origin, HIV co-infection and probable source/mechanism of infection. The Microsoft Excel ${ }^{\circledR} 2010$ program was used for structuring the data and making the tables. A descriptive analysis was performed by calculating the frequencies and obtaining the percentage values of the data of categorical variables. In addition, a comparison was made between the etiologies of viral hepatitis in relation to gender, age group, clinical form and race. The chi-square test was used to compare the proportions and verify the existence of an association between these variables, considering the significance level of $\mathrm{p}<0.05$. All statistical analyses were performed in Stata 12 software. This research was approved by the Ethics and Research Committee of the State University of Health Sciences of Alagoas (CAAE: 79447417.0.0000.5011).

\section{Results}

632 medical records were analyzed with confirmed cases of viral hepatitis treated and diagnosed from January 2010 to December 2015. The year with the highest number of cases was 2011, corresponding to 29.7\% (188) of the cases treated and diagnosed in the period. 2014 presented the lowest percentage of cases with a number of $8.1 \%$ (51) (Table 1 ).

Regarding the etiological classification, a higher number of cases of hepatitis A was observed responsible for $64.5 \%$ (408) of the cases diagnosed and treated in this period. Followed by HBV with $22.5 \%$ (142) and HCV with $11.7 \%$ (74) of the cases. Not only that but it was also observed the presence of HAV + HBV co-infections (0.5\%), HAV + HCV $(0.2 \%)$ and HBV $+\mathrm{HCV}(0.6 \%)$. No cases of hepatitis D and E were treated/diagnosed in the period studied (Table 2). It was observed that the highest number of infections were caused by HAV, kept sustained throughout the analyzed period, except for 2014, in which there was a decrease in the number of hepatitis A cases and an increase in those related to $\mathrm{HBV}$ infections (Table 1 ). In regard to gender there was a higher occurrence of cases among males with $59.5 \%$ (376) of the cases, followed by females, with a 
Table 1. Number of cases of viral hepatitis according to year of diagnosis, etiology, race and sex, from January 2010 to December 2015 , in the population treated at a reference hospital in Alagoas.

\begin{tabular}{|c|c|c|}
\hline YEAR & No & $\%$ \\
\hline 2010 & 129 & 20.4 \\
\hline 2011 & 188 & 29.7 \\
\hline 2012 & 112 & 17.7 \\
\hline 2013 & 79 & 12.5 \\
\hline 2014 & 51 & 8.1 \\
\hline 2015 & 73 & 11.6 \\
\hline \multicolumn{3}{|l|}{ ETIOLOGY } \\
\hline A & 408 & 64.5 \\
\hline B & 142 & 22.5 \\
\hline C & 74 & 11.7 \\
\hline$A+B$ & 3 & 0.5 \\
\hline$B+C$ & 4 & 0.6 \\
\hline$A+C$ & 1 & 0.2 \\
\hline \multicolumn{3}{|l|}{ SEX } \\
\hline Male & 376 & 59.5 \\
\hline Female & 256 & 40.5 \\
\hline \multicolumn{3}{|l|}{ RACE } \\
\hline Brown & 584 & 92.4 \\
\hline White & 17 & 2.7 \\
\hline Black & 15 & 2.4 \\
\hline Undeclared & 16 & 2.5 \\
\hline
\end{tabular}

Table 2. Number of cases of viral hepatitis according to the year of diagnosis and etiology, from January 2010 to December 2015, in the population treated at a reference hospital in Alagoas.

\begin{tabular}{ccccc}
\hline \multirow{2}{*}{ YEAR } & A & B & C & Others \\
\cline { 2 - 5 } & No (\%) & No (\%) & No (\%) & No (\%) \\
\hline 2010 & $81(62.8)$ & $33(25.6)$ & $13(10.1)$ & $2(1.5)$ \\
2011 & $139(73.9)$ & $30(15.6)$ & $18(9.6)$ & $1(0.5)$ \\
2012 & $66(58.9)$ & $28(25)$ & $18(16.1)$ & $0(0)$ \\
2013 & $59(74.7)$ & $15(19)$ & $4(5.1)$ & $1(1.3)$ \\
2014 & $17(33.3)$ & $23(45.1)$ & $8(15.7)$ & $3(5.8)$ \\
2015 & $46(63)$ & $13(17.8)$ & $13(17.8)$ & $1(2.7)$ \\
Total & 408 & 142 & 74 & 8 \\
\hline
\end{tabular}

percentage of $40.5 \%$ (256) (Table 1 ). This pattern occurred among all etiological types of hepatitis during the analyzed timeframe. There was no significant relationship between the etiologies and the sex in the viral hepatitis cases in this study ( $\mathrm{p}=0.855$ ).

As to the race/color of the individuals, the highest number of cases occurred in the brown race, with $92.4 \%$
(584) of the cases, followed by the white race with $2.7 \%$ (17) and black, corresponding to $2.4 \%$ (15). In $2.5 \%$ of the cases the field referring to the information "race" was filled as "undeclared" in the medical records (Table 1). It was not seen any relationship between etiologies of the viral hepatitis and the race in the cases studied ( $p=0.063$ ). Out of all cases analyzed, 1.4\% (9) also had HIV infection, 0.6\% of which corresponded to HBV (5) and $0.8 \%$ to HCV (4).

The results showed a predominance of the acute clinical form, with $70.3 \%$ (444) of the cases. The chronic form occurred in $29.1 \%$ of the cases. Another $0.6 \%$ of the cases were clinically classified as inconclusive, as they did not present sufficient information in the medical records to determine its form (Table 3 ). The predominance of cases classified as acute is justified by the large number of hepatitis A cases, which corresponded to $91.8 \%$ (408) of the cases. However, the etiologies responsible for chronic forms were $\mathrm{HBV}$ and $\mathrm{HCV}$, with 57.9\% (106) and 39.3\% (72) of cases, respectively. A significant relationship was observed in the association between the etiologies of viral hepatitis and the clinical form in the sample studied $(p<0.001)$ (Table 3$)$. The distribution according to the age group observed in the table showed a higher number of cases between the age groups 6-9 years (119) and $10-19$ years (144), totaling $41.6 \%$ of the cases (260). Followed by the predominance of the age group 20-39 years with $25 \%$ of the cases (158).

In addition, it was observed that the cases of hepatitis $\mathrm{A}$ were often observed among those who are under 20 years of age, mainly up to 9 years of age, where it represented $100 \%$ of the cases occurring in this age group. Between 20-39 years the highest number of cases were related to HBV infection (59.9\%) and above 40 years of age the cases of hepatitis $\mathrm{C}$ were the ones that stood out (Table 4). The sample studied shows a significant relationship in the association of the etiologies of viral hepatitis with the age group $(\mathrm{p}<0.001)$.

According to origin, it was observed that $91.4 \%$ (578) of the cases came from the mesoregion of Eastern Alagoas, $57 \%$ (329) of these coming from Maceió. The other 5.5\% (35) and 3.1\% (19) originally came from Agreste and Sertão Alagoano, respectively. After observing the variables related to the probable source/mechanism of infection, the lack of information in most of the medical records analyzed (31.6\%) is highlighted, which made it difficult to characterize this variable.

Despite this limitation, it was observed that among the cases of hepatitis A that presented this information, $64.1 \%$ (182) reported suspicious water/food consumption, 20.6\% (84) were related to household contamination and 2.4\% (10) reported contact with a suspected case. In 30.8\% (124) medical records this information was ignored and $1.7 \%(8)$ cases denied exposure to associated factors.

The Table 5 shows distribution of cases of hepatitis $\mathrm{B}$ and $\mathrm{C}$ according to the probable source/mechanism of infection, excluding those in which this information was ignored. It was observed that, among the cases of hepatitis B, the sexual transmission form stood out, corresponding to $29.7 \%$ (28) of the cases related to this etiology. Regarding hepatitis C, 23.5\% (12) of the cases reported a previous history of blood transfusion (23.5\%). 
Table 3. Distribution of cases of viral hepatitis according to the clinical form, from 2010 to 2015, in the population treated in a reference hospital in Alagoas.

\begin{tabular}{lcccccc}
\hline & $\mathbf{A}$ & $\mathbf{B}$ & $\mathbf{C}$ & $\mathbf{\text { Other }}$ & Total & p Value \\
\cline { 2 - 5 } & $\mathbf{N o}(\%)$ & $\mathbf{N}(\%)$ & $\mathbf{N}(\%)$ & $\mathbf{N}(\%)$ & $\mathbf{N}(\%)$ & \\
\hline Acute & $408(91.8)$ & $32(7.2)$ & $2(0.5)$ & $2(0.5)$ & $444(70.3)$ & \\
Chronic & $0(0)$ & $106(57.9)$ & $72(39.3)$ & $5(2.7)$ & $183(28.9)$ & $<0.001$ \\
Inconclusive & $0(0)$ & $4(2.8)$ & $0(0)$ & $1(20)$ & $5(0,8)$ & \\
Total & 408 & 142 & 74 & 8 & 632 & \\
\hline
\end{tabular}

Table 4. Distribution of viral hepatitis cases according to age group, from 2010 to 2015 in the population treated at a reference hospital in Alagoas.

\begin{tabular}{|c|c|c|c|c|c|c|}
\hline \multirow{2}{*}{$\begin{array}{l}\text { AGE } \\
\text { CATEGORY }\end{array}$} & A & B & C & Other & Total & \multirow{2}{*}{ p Value } \\
\hline & No (\%) & No (\%) & No (\%) & No (\%) & No (\%) & \\
\hline$<5$ & $84(20.5)$ & $0(0)$ & $0(0)$ & $0(0)$ & 84 (13.3) & \multirow{7}{*}{$<0.001$} \\
\hline $6-9$ & $118(28.9)$ & $0(0)$ & $0(0)$ & $1(12.5)$ & 119 (18.8) & \\
\hline $10-19$ & 137 (33.6) & $4(2.8)$ & $1(1.3)$ & $2(25)$ & $144(22.8)$ & \\
\hline $20-39$ & $59(14.6)$ & 85 (59.9) & $12(16.2)$ & $2(25)$ & $158(25)$ & \\
\hline $40-59$ & $8(1.9)$ & $44(31)$ & $45(60.8)$ & $3(37.5)$ & $100(15.8)$ & \\
\hline$>59$ anos & $2(0.5)$ & $9(6.3)$ & $16(21.6)$ & $0(0)$ & $27(4.3)$ & \\
\hline Total & 408 & 142 & 74 & 8 & 632 & \\
\hline
\end{tabular}

Table 5. Distribution of hepatitis B and C cases according to the probable source/mechanism of exposure from 2010 to 2015 in the population treated at a reference hospital in Alagoas.

\begin{tabular}{lcr}
\hline & B & \multicolumn{1}{c}{ C } \\
\cline { 2 - 3 } & No (\%) & \multicolumn{1}{c}{ No (\%) } \\
\hline Sexual & $28(29.7)$ & $3(5.9)$ \\
Hemodialysis & $0(0)$ & $3(5.9)$ \\
Surgical treatment & $17(18.1)$ & $11(21.5)$ \\
Dental treatment & $13(13.8)$ & $9(17.6)$ \\
Transfusion & $3(3.2)$ & $12(23.5)$ \\
Use of injectable drugs & $1(1.1)$ & $6(11.7)$ \\
Sharing of personal objects & $4(4.2)$ & $4(7.8)$ \\
Accident with biological material & $1(1.1)$ & $1(1.9)$ \\
Tattoo/piercing & $3(3.2)$ & $3(5.9)$ \\
Denied exposure & $25(26.5)$ & $5(9.8)$ \\
\hline
\end{tabular}

\section{Discussion}

The results obtained in the study showed that there was a decrease in the number of cases of viral hepatitis diagnosed during the analyzed period. Regarding the etiology, the results obtained agree with a study conducted in Minas Gerais, which also showed a higher number of hepatitis A cases among notifications regarding viral hepatitis (Ferreira et al., 2017). It was observed that individuals $<9$ years old, all cases were confirmed to be hepatitis $A$, which is compatible with the findings described by the Ministry of Health $(\mathrm{MoH})$ between 1999 and 2016, which point out to a higher occurrence of cases related to this etiology between $<10$ years, corresponding to $54.5 \%$ of the cases reported throughout the country (Brasil, 2017). This is justifiable because this age group is represented by school-age children, who are more susceptible to infection mechanisms related to this etiology (Vieira et al., 2010).

In addition, it was observed that the highest percentage of cases found between 20-39 years of age corresponds to HBV, which is compatible with a study conducted by Martins et al. (2011), in the city of Salvador. A similar profile was also observed in Florianópolis and in another study conducted in a Central Laboratory of Pará (Aquino et al., 2008; Silva et al., 2013). A study conducted in a town in the state of Paraná showed that the highest occurrence of hepatitis $C$ cases are the age group $>40$ years, similar to the profile found in this study (Rodrigues Neto et al., 2012). Some studies relate this finding to the risk behavior for hepatitis B and C observed more frequently among these age groups (Ferreira et al., 2017). The high number of cases among males occurring in all etiological types is compatible with 
the national profile touted by the MoH (Brasil, 2017). However, it does not agree with the results obtained in the study conducted in a public service in São Paulo, which despite having demonstrated the highest occurrence of hepatitis B cases among men (62.5\%), there was a slight predominance of cases of hepatitis $C$ among women (51.5\%) (Cruz et al., 2009). Although there is no evidence to prove the greater susceptibility of males, some studies attribute this finding to the higher occurrence of risk behavior among men, such as injecting drug use, sexual promiscuity, and unprotected sexual intercourse. However, this hypothesis still needs further investigation (Gomes et al., 2010; Araújo et al., 2012).

The high number of cases observed among the brown race in this study does not agree with a study conducted by Bortolucci et al. (2015) in Paraná, in which 78.8\% of hepatitis B cases occurred among the white race. However, the results of a study conducted in Tocantins showed that the brown race was the most affected by HCV, with $80 \%$ of the cases (Gusmão et al., 2017). A similar result was also presented by a study conducted in Piauí, with a percentage of $70.4 \%$ of hepatitis A cases occurring among the brown race (Barbosa et al., 2017). With regard to the divergence of the results related to skin color of the infected in the northeast and south, this fact is possibly associated with regional differences that would justify this fact as the origin of the individuals who initiated the colonization of these areas (influence of slave traffic in the northeast and colonization of European immigrants in the south) (Motter, 2015; Graham, 2002).

Regarding the clinical form, the large number of acute infections is justified by the higher frequency of cases of HAV infection, since the disease has a self-limited and predominantly benign course ${ }^{10}$. A study conducted with cases of hepatitis A reported in the State of Piauí found that, similar to the results obtained in this study, the acute clinical form corresponded to $94.9 \%$ of the cases related to this etiology (Barbosa et al., 2017).

The chronic form was predominant in patients with $\mathrm{HBV}$ and HCV, which is compatible with the results described by a study conducted in São Paulo, which demonstrated the evolution to chronic hepatitis in 54.5\% and $81.7 \%$ of cases related to HBV and HCV infection (Cruz et al., 2009). In addition, Bortolucci et al. (2015) when evaluating the prevalence of hepatitis B in Paraná concluded that $88 \%$ of the cases evolved to the chronic form, while $10 \%$ stayed in the acute form. In another study conducted with cases of hepatitis $C$ in the Northern region of Brazil, it was observed that $91 \%$ of the cases were related to the chronic form of infection (Gusmão et al., 2017).

Regarding the probable source/mechanism of infection, among the cases of hepatitis $\mathrm{A}$, the consumption of suspicious water/food stood out, a finding similar to that described by Barbosa et al. (2017), which showed that $74.5 \%$ of the cases of hepatitis A reported during the time studied was caused by the consumption of contaminated water or food as the probable source of infection, followed by household forms of transmission. Despite the large amount of cases that did not present information about the probable source/mechanism of infection, it was observed that, among the cases of HBV infection, there was emphasis in the form of transmission defined as "sexual". A similar result was observed in a study conducted in a public service in São Paulo, which showed that sexual transmission was attributed to $32.1 \%$ of hepatitis B cases (Cruz et al., 2009). It is known that, in Latin America, the sexual transmission is considered the most frequent among the cases related to this etiology (Tanaka, 2000). A study conducted in the city of Salvador also pointed out to sexual transmission being the most prevalent mechanism among the cases of hepatitis $B$ analyzed (Martins et al., 2011).

Regarding hepatitis $C$ cases, the history of blood transfusion and surgical procedures were predominant. A similar result was observed in the study conducted by Cruz et al. (2009) in a public service in São Paulo, which showed a higher prevalence of surgical treatment and blood transfusion among cases of hepatitis C. With higher proportions in a study conducted in northern Pará, 61\% of their interviewees received blood transfusion at some point in their lives (Oliveira-Filho et al., 2010). Beginning in 1993, when screening for hepatitis B and C was introduced in blood banks, there was a considerable reduction in the transmission of this disease through transfusions (Martins et al., 2010). It was observed that the use of injectable drugs was also reported by a small number of the sample in studies conducted by Moia et al. (2014) and Gheorghe et al. (2010).

According to the data from the Ministry of Health described in the Epidemiological Bulletin of Viral Hepatitis, among the 27 Brazilian capitals, 08 had an incidence rate of hepatitis A cases higher than the national rate, with Maceió placing 8th in this rank, which is compatible with the high prevalence of cases of HAV infection in the capital Maceió, observed in this study (Brasil, 2017, 2018). Regarding HIV virus co-infection, it was evidenced in this study that the related etiologies were hepatitis B and C. It is known that HIV carriers are more susceptible to other STIs, which can be explained by the fact that such infections have the same mechanism of transmission (Dos Santos et al., 2017).

In conclusion, this study allowed us to know the epidemiological profile of viral hepatitis in a reference hospital in Alagoas. The results agreed with what is described in the literature. Data analysis also demonstrated the issue of incomplete completion of medical records, given the large amount of information ignored. This hinders the investigation and notification process. In addition, the scarcity of similar studies in the State of Alagoas was notorious. It is noticeable the great need for planning and implementing actions and strategies that promotes improvements in the sanitary and hygiene conditions of the population, as well as vaccination against hepatitis $A$ and $B$. In addition, it is indispensable to advise the population through campaigns against transmission among the population, in order to combat this important public health problem. 


\section{References}

AQUINO, J.A., PEGADO, K.A., BARROS, L.P. and MACHADO, L.F.P., 2008. Soroprevalência de infecções por vírus da hepatite $B$ e vírus da hepatite $\mathrm{C}$ em indivíduos do Estado do Pará. Revista da Sociedade Brasileira de Medicina Tropical, vol. 41, no. 4, pp. 334337. http://dx.doi.org/10.1590/S0037-86822008000400003. PMid: 18853003

ARAÚJO, T.M., SÁ, L.C., SANTOS, A.S., TAPETY, F.I. and MESQUITA, G.V., 2012. Prevalência da Hepatite B em usuários do Laboratório Central do Piauí. Revista Enfermagem UERJ, vol. 20, no. 2, pp. 229-234.

AZEVEDO, A.O., SANTOS, M.M., ROIG, J. J. and SOUZA, D.L.B., 2015. Incidência das hepatites virais no Brasil de 1997 a 2020. Revista de Enfermagem UFPE on line, vol. 9, no. 4, pp. 7375-7382. http://dx.doi.org/10.5205/reuol.7275-62744-1SM.0904201524.

BARBOSA, G.S., NEIVA, R.C., BARRETO, T.S., OLIVEIRA, J.F., MOURA, H.C. and SANTOS, G.M., 2017. Caracterização epidemiológica e clínica dos casos de hepatite A notificados no Estado do Piauí - Brasil. Brazilian Journal of Surgery and Clinical Research, vol. 20, no. 2, pp. 47-53.

BORTOLUCCI, W.C., FERREIRA, F.N. and CORREA, N.A.B., 2015. Prevalência de hepatite $B$ no Estado do Paraná, Brasil, nos anos de 2008 a 2013. Revista Uningá, vol. 44, pp. 10-16.

BRASIL. Ministério da Saúde Secretaria de Vigilância em Saúde. Departamento de Vigilância, Prevenção e controle das IST, do HIV/Aids e das Hepatites Virais. Protocolo clínico e diretrizes terapêuticas para hepatite viral C e coinfecções. Brasília: Ministério da Saúde, 2015.

BRASIL. Ministério da Saúde Secretaria de Vigilância em Saúde. Departamento de Vigilância, Prevenção e controle das IST, do HIV/Aids e das Hepatites Virais. Manual técnico para o diagnóstico das hepatites virais. Brasília: Ministério da Saúde, 2018.

BRASIL. Ministério da Saúde Secretaria de Vigilância em Saúde. Departamento de Vigilância, Prevenção e controle das IST, do HIV/Aids e das Hepatites Virais. Boletim epidemiológico: hepatites virais. Brasília: Ministério da Saúde; 2017.

CRUZ, C.R.B., SHIRASSU, M.M. and MARTINS, W.P., 2009. Comparação do perfil epidemiológico das hepatites $B$ e $C$ em um serviço público de São Paulo. Arquivos de Gastroenterologia, vol. 46, no. 3, pp. 225-229. http://dx.doi.org/10.1590/S000428032009000300016. PMid:19918691.

DOS SANTOS, O.P., DE SOUZA, M.R., BORGES, C.J., NOLL, M., LIMA, F.C. and BARROS, P.S., 2017. Hepatites B, C e sífilis: prevalência e características associadas a coinfecção em soropositivos. Cogitare Enfermagem, vol. 22, no. 3, pp. e51693. http://dx.doi. org/10.5380/ce.v22i3.51693.

FERREIRA, V.M., GONÇALVES, E. and GONZAGA, L.M.O., 2017. Hepatites virais: epidemiologia dos casos notificados no estado de Minas Gerais entre 2005 e 2014. Revista Unimontes Científica, vol. 19, no. 1, pp. 1-9.

FONSECA, J.C.F., 2010. Histórico das hepatites virais. Revista da Sociedade Brasileira de Medicina Tropical, vol. 43, no. 1, pp. 322330. http://dx.doi.org/10.1590/S0037-86822010000300022. PMid:20563505.

GHEORGHE, L., CSIKI, I.E., IACOB, S., GHEORGHE, C., SMIRA, G. and REGEP, L., 2010. The prevalence and risk factors of hepatitis $\mathrm{C}$ virus infection in adult population in Romania: a Nationwide Survey 2006-2008. Journal of Gastrointestinal and Liver Diseases; JGLD, vol. 19, no. 4, pp. 373-379. PMid:21188327.
GOMES, D. T., TOCANTINS, F. R. and SOUZA, F. B. A., 2010. Perfil de portadores de hepatite $\mathrm{C}$ e a vulnerabilidade da população: potencialidades para a enfermagem. Revista de Pesquisa: Cuidado é Fundamental Online, vol. 2, pp. 512-515.

GRAHAM, R., 2002. Nos tumbeiros mais uma vez? O comércio interprovincial de escravos no Brasil. Afro-Ásia, vol. 27, pp. 121-160.

GUSMÃO, K.E., DIAS, F.C.F., DE SANTANA, V.M.X., CALADO, E.J.R., OLIVEIRA, V.D.S., OLIVEIRA, A.A., LOBO, P.H.P., LIBERATO, A.A., LOPES, A.B. and GUEDES, V.R., 2017. Perfil clínico-epidemiológico da hepatite $C$ na região Norte entre 2012 e 2015. Brazilian Journal of Surgery and Clinical Research, vol. 4, no. 2, pp. 41-45. http:// dx.doi.org/10.20873/uft.2446-6492.2017v4n2p41.

KAO, J.H. and CHEN, D.S., 2000. Transmission of hepatitis C vírus in Ásia: post and present perpectives. Journal of Gastroenterology and Hepatology, vol. 15, no. 15, suppl., pp. E91-E96. http:// dx.doi.org/10.1046/j.1440-1746.2000.02108.x. PMid:10921389.

LOK, A.S., MCMAHON, B. and PRACTICE GUIDELINES COMMITTEE, AMERICAN ASSOCIATION FOR THE STUDY OF LIVER DISEASES, 2011. Chronic hepatitis B. Hepatology (Baltimore, Md.), vol. 34, no. 6, pp. 1225-1241. http://dx.doi.org/10.1053/jhep.2001.29401. PMid:11732013.

MARTINS, M.M.F., VERAS, R.M. and COSTA, E.A.M., 2011. Hepatite B no Município de Salvador, Bahia, Brasil: padrão epidemiológico e associação das variáveis sociodemográficas. Revista Brasileira de Ciências da Saúde, vol. 20, no. 3, pp. 189-196. http://dx.doi. org/10.4034/RBCS.2016.20.03.03.

MARTINS, T., NARCISO-SCHIAVON, J.L. and SCHIAVON, L.L., 2010. Epidemiologia da infecção pelo virus da hepatite C. Revista da Associação Médica Brasileira, vol. 57, no. 1, pp. 107-112. http:// dx.doi.org/10.1590/S0104-42302011000100024. PMid:21390467.

MOIA, L.J.M.P., AMARAL, I.S.A., FARIAS, A.J.L. and SILVA, M.M.A., 2014. Infecção pelo vírus da hepatite $C$ em hospital de referência na Amazônia brasileira. Revista Paraense de Medicina, vol. 28, no. 3, pp. 1-7.

MOTTER, A.F.C., 2015. Colonização Europeia no NW do Rio Grande do Sul: primeiros sinais de desequilíbrios ambientais. Mercator, vol. 14, no. 1, pp. 105-112. http://dx.doi.org/10.4215/ RM2015.1401.0007.

NUNES, H.M., SOARES, M.C.P., BRITO, E.M.F., ALVES, M.M., SOUZA, O.S.C., BORGES, A.M., SILVA, I.S. and PAIXÃO, J.F., 2010. Prevalência de infecção pelos vírus das hepatites A, B, C e D na demanda de um hospital no Município de Juruti, oeste do Estado do Pará, Brasil. Revista Pan-Amazônica de Saúde, vol. 1, no. 2, pp. 105-111. http://dx.doi.org/10.5123/S2176-62232010000200013.

NUNES, H.M., SOARES, M.C.P., SARMENTO, V.P., MALHEIROS, A.P., BORGES, A.M., SILVA, I.S. and PAIXÃO, J.F., 2016. Soroprevalência da infecção pelos vírus das hepatites A, B, C, D e E. Revista Pan-Amazônica de Saude, vol. 7, no. 1, pp. 55-62. http://dx.doi. org/10.5123/S2176-62232016000100007.

OLIVEIRA-FILHO, A.B., PIMENTA, A.S.C., ROJAS, M.F.M., CHAGAS, M.C.M., CRESPO, D.M., CRESCENTE, J.A.B. and LEMOS, J.A.R., 2010. Likely transmission of hepatitis $C$ virus through sharing of cutting and perforanting instruments in blood donors in the state of Pará, Northern Brazil. Cadernos de Saude Publica, vol. 26, no. 4, pp. 837-844. http://dx.doi.org/10.1590/S0102311X2010000400025. PMid:20512223.

OLIVER, J.C., PRADO, C.G., OLIVEIRA, C.C., ALVARENGA, D.J., COSTA, D.R.S.A., GERMANO, J.D.L., NERY, J.M., NERY, J.O., FERREIRA, J.N., SELICANI, L.F., SOUZA, L.R.A., ROSA, L.M., MONTEIRO, L.D.O., SIQUEIRA, N.G. and VEIGA, S.M.O.M., 2013. Hepatite C: prevenção e diagnóstico. Revista da Universidade Vale do Rio Verde, vol. 11, no. 1, pp. 19-29. http://dx.doi.org/10.5892/968. 
PEREIRA, F.E.L. and GONCALVES, C.S., 2003. Hepatite A. Revista da Sociedade Brasileira de Medicina Tropical, vol. 36, no. 3, pp. 387400. http://dx.doi.org/10.1590/S0037-86822003000300012. PMid:12908041.

PRADO, T. and MIAGOSTOVICH, M.P., 2014. Virologia ambiental e saneamento no Brasil: uma revisão narrativa. Cadernos de Saude Publica, vol. 30, no. 7, pp. 1367-1378. http://dx.doi. org/10.1590/0102-311X00109213. PMid:25166934.

RODRIGUES NETO, J., CUBAS, M.R., KUSMA, S.Z. and OLANDOSKI, M., 2012. Prevalence of hepatitis $C$ in adult users of the public health service of São José dos Pinhais--Paraná. Revista Brasileira de Epidemiologia, vol. 15, no. 3, pp. 627-638. http://dx.doi. org/10.1590/S1415-790X2012000300016. PMid:23090309.
SILVA, A.C.L.G., TOZATTI, F., WELTER, A.C. and MIRANDA, C.D.C., 2013. Incidência e mortalidade por hepatite B, de 2001 a 2009: uma comparação entre o Brasil, Santa Catarina e Florianópolis. Cadernos Saúde Coletiva, vol. 21, no. 1, pp. 34-39. http://dx.doi. org/10.1590/S1414-462X2013000100006.

TANAKA, J., 2000. Hepatitis B epidemiology in Latin America. Vaccine, vol. 18, suppl. 1, pp. S17-s9. http://dx.doi.org/10.1016/ S0264-410X(99)00455-7. PMid:10683537.

VIEIRA, M., GOMES, J., NASCIMENTO, W., PEREIRA, G., DIAS, O. and LEITE, M., 2010. Aspectos epidemiológicos das hepatites virais no norte de Minas Gerais. Revista Baiana de Saúde Pública, vol. 34, no. 2, pp. 348-358. http://dx.doi.org/10.22278/23182660.2010.v34.n2.a40. 